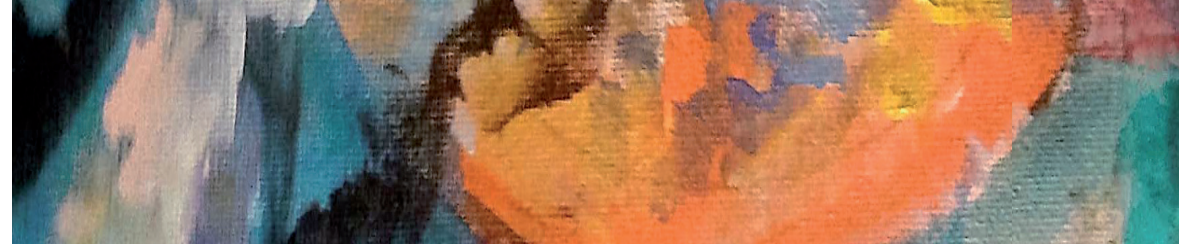

Entreculturas 11 (2021) pp. 53-68 - ISSN: 1989-5097

\title{
LA MEMORIA "VIAGGIANTE" FRA IDENTITÀ E TRADUZIONE
}

\section{The "Travelling" Memory between Identity and Translation}

\author{
(D) S. Cristian Troisi \\ Universidad de Málaga
}

Recibido: 13 de octubre de 2020

Aceptado: 13 de enero de 2021

Publicado: 27 de febrero de 2021

\begin{abstract}
One of the main characteristics of memory is its being in motion, which crosses in a transversal way: nations, eras and technologies. It is also one of the most important aspects in the identity construction; defines and punctuates the life of an individual or social group, indelibly characterizes them over time, is re-mediated within the media and the different groups of our society. His transnational "journey" that travels through space, time and technologies in continuous mediation and redefinition is assimilated to the translation. It is undeniable how memory, identity and translation are intimately connected with each other and with what is enclosed in the human essence, which must be understood in a dialectic of implication and ipseity/Alterity.
\end{abstract}

KEYWORDS: cultural memory, translation, identity, ipseity, alterity.

\section{RIASSUNTO}

Una delle caratteristiche principali della memoria è il suo essere in movimento, il quale, attraversa in maniera trasversale: nazioni, epoche e tecnologie. Rappresenta, inoltre, uno degli aspetti più rilevanti nella costruzione dell'identità; definisce e scandice la vita di un individuo o un gruppo sociale, li caratterizza indelebilmente nel tempo, viene ri-mediata all'interno dei media e dei diversi gruppi della nostra società. Questo suo "viaggio" transnazionale che percorre lo spazio, il tempo e le tecnologie in una continua mediazione e ridefinizione lo si assimila al medesimo cammino che in una certa forma compie la traduzione. È innegabile come memoria, identità e traduzione siano intimamente connesse fra di loro e a ciò che è racchiuso nell'essenza umana, che deve intendersi in una dialettica dell'implicazione e dell'ipseità/alterità.

PAROLE CHIAVE: memoria culturale, traduzione, identità culturale, ipseità, alterità. 


\section{LA MEMORIA “VIAGGIANTE” FRA IDENTITÀ E TRADUZIONE}

Entreculturas 11 (2021) pp. 53-68

\section{INTRODUZIONE}

Al momento attuale è innegabile la rilevanza del legame tra traduzione e memoria. Addentrandoci più nel particolare, ci si rende conto che il legame è molto più articolato visto che esso comprende anche altri elementi interconnessi fra loro quali: la letteratura, la lingua e soprattutto l'identità.

La memoria attraverso i suoi plurimi aspetti e le sue policrome sfumature è indubbiamente un punto di riferimento culturale ed identitario, nel suo divenire tramite privilegiato del concetto di alterità, che deve essere recepito non in contrapposizione a quest'ultimo, e quindi in un'ottica di rottura e di prevaricazione, ma ad esso complementare e consequenziale, al quale legarsi in modo da completarlo, ridefinendolo. Come evidenzia Ciaramelli, «rispetto all'identità del Medesimo o "medesimezza", che si colloca necessariamente al di qua o al di fuori dell'alterità, l'identità del "sé" o "ipseità" è caratterizzata da un originario e intrinseco rapporto o riferimento all'alterità. La dialettica ipseità/alterità, costitutiva della trama stessa della soggettività, è una dialettica dell'implicazione, e non dell'esclusione o dell'integrazione» (Ciaramelli 1991: 59).

Di conseguenza, bisogna tenere presente che l'identità è soprattutto costituita da una relazione dialettica tra un individuo e gli altri individui della società. Senza l'Altro, non ci sarebbe identità.

Dunque, quando si parla dell'identità di una persona, deve essere tenuta in considerazione anche l'identità degli altri, l'alterità. Dall'interazione culturale prendono forma e si costituiscono ognuna delle culture, dalla loro differenza nasce il concetto di identità culturale (Vallespir 1999: 45).

Il nostro scopo sarà quindi, quello di rendere, in una certa misura, evidente la complessa trama di relazioni che legano la memoria e l'identità alla traduzione. Definendo e analizzando le caratteristiche principali di questi elementi, osserveremo come la loro comune particolarità sia, il carattere attivo, dinamico, quel incessante movimento che li porta ad essere itineranti e ad evolversi costantemente adattandosi ai continui cambi e influenze esterne che si avvicendano nel corso del tempo, ridefinendoli. È in quest'aspetto di continua mediazione e ri-mediazione che memoria, identità $\mathrm{e}$ tradizione sembrano seguire un percorso comune.

\section{IDENTITÀ CULTURALE}

Il concetto di identità culturale è molto legato a quello di cultura e implica il senso di appartenenza a un gruppo sociale, avendo in comune con esso caratteristiche culturali quali costumi, valori e credenze, ecc. L'identità, come la cultura da cui deriva la nozione, non è un concetto cristallizzato, ma viene ricreata individualmente, collettivamente e costantemente attraverso influenze esterne. (Molano 2007: 73; Bakúla 2000: 169)

Come accennato nel paragrafo precedente, in termini socio-antropologici, sarebbe impossibile concepire una cultura isolata dalle altre, dato che l'identità nasce dall'interazione, dallo scambio, dal contatto con una identità "altra", senza questa relazione di vicinanza non sussisterebbe quella ripetizione reciproca fra le identità, che viene generata dalla differenziazione che è naturalmente una riaffermazione della propria identità nei confronti di un'altra identità.

Sebbene il concetto di identità trascenda i confini nazionali essendo legato quasi costantemente ai movimenti migratori: "la diversidad cultural es casi siempre fruto de los movimientos migratorios, las migraciones han sido una constante a lo largo de toda la historia de la humanidad y se han sucedido prácticamente en todos los lugares. Y los motivos han sido tradicionalmente de dos tipos: socioeconómicos y políticos." (Vallespir 1999: 45) la genesi del concetto vede come culla abituale un elemento statico come il territorio.

Storicamente, i costituenti base della identità culturale di una nazione, di una regione, di una terra, ecc. sono elementi che contraddistinguono fortemente la cultura di un luogo, nel modo in cui lo sono: la lingua, le relazioni fra i membri della comunità, la religione, le relazioni sociali che rappresentano un patrimonio immateriale, perché intangibili e anonimi per cui, trascendono il piano individuale in 


\section{S. Cristian Troisi}

Entreculturas 11 (2021) pp. 53-68

quanto prodotti dalla colletività: "La identidad sólo es posible y puede manifestarse a partir del patrimonio cultural, que existe de antemano y su existencia es independiente de su reconocimiento o valoración.” (Bákula 2000: 169)

Il territorio rappresenta l'humus mentre la società rappresenta l'agente attivo, delineando il proprio patrimonio culturale, istituendo e identificando elementi da "canonizzare" e da acquisire spontaneamente come propri i quali diventano il punto di riferimento per l'identità per la quale è essenziale essere riconosciuta nel proprio ambiente fisico e sociale. Ė quel costante riconoscimento che conferisce all'identità culturale il suo carattere attivo.

L'identità è indissolubilmente collegata alla storia e al patrimonio culturale. Non possiamo parlare d'identità senza l'esistenza della memoria, senza la capacità di riconoscere e riconoscersi in un passato comune, privati di elementi simbolici, di quel bagaglio culturale che inconsciamente possediamo sin dalla nascita in quanto membri di una comunità e che ci permette di non ripartire da zero e costruire progressivamente, passo dopo passo il nostro futuro.

Tutto questo lo si evince inequivocabilmente, anche in chiave europea, da un documento prodotto dal Committee on Culture, Youth, Education, Media and Sport nel quale si riconosce l'importanza della costituzione di un'identità comune strettamente legata alla memoria storica allo scopo di costruire una comune visione europea ed un camino comunitario verso il futuro:

European cultural identity is closely linked to the historical memory of European citizens, their social consciousness and political attitudes. The political entity and efficiency of the European Union presupposes a European cultural identity and expression. A value like 'unity in diversity' can emerge only through the participation of European citizens in European civil society, where culture plays a central role. It is obvious, then, that such a cultural identity must be closely linked to the democratic participation of European citizens in the vision of a common European destiny. (Committee on Culture, Youth, Education, Media and Sport 2003: 2)

\section{MEMORIA COLLETTIVA, SOCIALE, CULTURALE E LE SCIENZE DELLA TRADUZIONE}

Non possiamo parlare di memoria, e nello specifico di memoria collettiva e memoria culturale senza considerare ed esaminare il lavoro del sociologo Maurice Halbwachs, le teorie contenute nelle sue opere rappresentano il punto di partenza essenziale per una analisi epistemologica del fenomeno memonico nella sua declinazione sociologica, o più accuratamente, nelle sue ramificazioni socio-antropologiche. Senza termini medi, il corpus delle sue opere ci aiuta, individuando, ordinando, e costruendo o ricostruendo il vissuto personale in termini di relazioni, che, senza ombra di dubbio, si stabiliscono nei gruppi a cui l'individuo si relaziona interpretando il proprio ruolo nella società come componente attivo e/o passivo, essendo non solo individuo ma parte di un macro gruppo o di diversi gruppi nel corso della propria esistenza.

Il sociologo francese asserisce che ogni singola memoria è iscritta e partecipa alla costituzione di una più grande, la memoria collettiva, che ne determina i ricordi come pure la sua strutturazione. I ricordi personali, quindi, la propria memoria viene condizionata dal gruppo a cui si appartiene, primo fra tutti la famiglia, pertanto può essere postulato più radicalmente, che ricordiamo in quanto membri di un gruppo. Sinotticamente questo si concretizza in una distinzione fra:

- memoria storica, che è la ricostruzione dei dati presenti proiettati in un passato reiventato;

- memoria collettiva che meravigliosamente ricompone il passato attenendosi all'esperienza ed ai ricordi di una comunità, o un gruppo di individui o diversi gruppi eterogenei o omogenei fra di loro;

- memoria individuale che non è in grado di farlo autonomamente ma che permette ai diversi componenti di una comunità o di un gruppo di riedificare il passato ricostruendo i propri ricordi. (Betancourt Echeverry 2004: 126) 


\section{LA MEMORIA “VIAGGIANTE” FRA IDENTITÀ E TRADUZIONE}

Entreculturas 11 (2021) pp. 53-68

Traspare in maniera evidente la rilevanza dei gruppi, della "collettività" in Halbwachs, che segue le dinamiche dell'associazione e dissociazione. Quindi, i gruppi si costituiscono, vivono e si estinguono; ciò nonostante, la memoria ad essi legata, in una certa forma, gli sopravvive.

Nella formazione dei gruppi, una componente essenziale è costituita dall'affettività. Halbwachs (2001) evidenzia il valore fondamentale delle "communautés affectives", ovvero le relazioni affettive che legano i membri di un gruppo conferendo ai ricordi accenti unici e scandendo, di fatto, la vita stessa del gruppo. Oltre al rapporto tra i membri dello stesso gruppo, è essenziale che la costruzione della memoria e il suo rafforzamento passino attraverso l'interazione tra i diversi gruppi. Quei gruppi in cui si transita durante la vita, devono essere legati ai fatti costitutivi del passato personale di un individuo, che sono inversamente proporzionali alla sua grandezza, di fatto più grande è il luogo in cui il gruppo registra gli eventi e meno incisiva sarà quella registrazione cosi come il suo contributo allo sviluppo della vita e del pensiero di ogni singolo membro.

Di centrale importanza, rileva Halbwachs, è nella teoria della memoria l'opposizione fra memoria storica e memoria collettiva.

L'attenzione del sociologo francese si focalizza nel sottolineare l'incapacità di localizzare e conservare il ricordo personale e tantomeno di coadiuvalo nella propria costruzione. $\mathrm{Al}$ contrario della storia, che si vede costretta a frazionare il tempo a dividerlo in periodi o epoche, la memoria collettiva non ha la necessità di delimitare e sezionare il tempo, ciò che conta veramente sono i legami affettivi che ne rappresentano il vero motore, la linfa vitale che mai troveremo nella memoria storica. In un romanzo, poco importa sapere in che periodo storico si snoda la sua trama, ciò che conta è il contenuto psicologico, la componente emozionale, i suoi legami affettivi ossia, quelli che intercorrono fra i componenti di una famiglia o tuttalpiù di un gruppo, che di fatto potrebbero appartenere a qualsiasi periodo storico senza che l'interesse da parte del lettore sfiorisca.

Fin da bambino, inconsapevolmente, l'essere umano è immerso nel passato. Attraverso la lingua, l'oralità, i racconti, le fiabe, i proverbi, ecc. vengono trasmessi tutti quei contenuti memonici e mitici che appartengono a un passato vivo, presente, molto più di qualsiasi forma di memoria, fissata tramite la scrittura in un testo.

Questo patrimonio vivo, che è parte di una comunità o un gruppo, riveste un ruolo fondamentale dato che in seguito formerà una solida base d'appoggio sulla quale costruire e alimentare i futuri ricordi e pertanto la costruzione della memoria. Dal concetto di memoria collettiva prende forma e si sviluppa quello di memoria culturale che a sua volta si avvale del basilare apporto della memoria sociale.

Agli albori del secolo scorso Aby Moritiz Warburg storico dell'arte di origini ebraiche, seguendo una intuizione che si basava nella sperimentazione su base euristica della memoria e le sue connessioni con le immagini, si rese conto di come elementi arcaici persistessero nelle opere d'arte senza che necessariamente rispondessero al principio di causa ed effetto, grazie a queste intuizioni elaborò, successivamente, il proprio metodo che consiste nel catalogare ed esporre le immagini seguendo delle associazioni mentali non canoniche e non evidenti.

Il frutto di tali illuminazioni si esplicita nell'atlante mnemonico il Bilderatlas Mnemosyne.

In seguito, grazie a queste sue osservazioni verrà formulato il concetto di "memoria sociale" la cui idea cardine si basa nel considerare le immagini come parte attiva del processo mnemonico essendo queste ultime portatrici di memoria.

Formulando il concetto di travelling memory, nel quale l'incessante peregrinazione di media, contenuti, forme e pratiche della memoria, i loro continui cammini e le continue variazioni nel tempo e nello spazio, attraverso confini sociali, linguistici e politici sono alla base del concetto di memoria "viaggiante".

Erll sottolinea una importante caratteristica di Warburg:

What Warburg focuses on is the movement, the migration or travel, of symbols across time and space. And this is in fact how I would like to conceive of transcultural memory: as the incessant wandering of carriers, media, contents, forms, and practices of memory, their continual 'travels' and ongoing trans- 


\section{S. Cristian Troisi}

\begin{abstract}
formations through time and space, across social, linguistic and political borders. Such an understanding of memory as fundamentally 'travelling memory' can certainly be backed by the sheer evidence of mnemohistory. The current age of accelerated globalization has brought forth global media cultures, in which historical novels are quickly translated, movies dealing with the past are screened simultaneously in different corners of the globe, and worldwide TVaudiences can have mass-mediated experience in real time (as, for example, in the case of ' $9 / 11$ ' or the inauguration of the American president Obama). But as Warburg's work reminds us, it is actually since ancient times that memory lives in and through its movements, and that mnemonic forms and contents are filled with new life and new meaning in changing social, temporal and local contexts (Erll 2011: 11).
\end{abstract}

La storia quindi come forma di memoria simbolica caratterizzata per il movimento attraverso il tempo e lo spazio che a sua volta incontra altre forme simboliche. L'idea di memoria sociale warburgheriano, completa il concetto di memoria collettiva, e dà forma a quello di memoria culturale, che a noi interessa più da vicino.

I concetti di memoria sociale e memoria colletiva convergono nella memoria culturale, nascono da una intuizione dell'egittologo Jan Assman, il quale introduce il concetto di "comunicative memory" per differenziarlo dal halbawhasiano "collective memory" che successivamente verrà poi sviluppato principalmente da Aleida Assman divenendo "cultural memory".

La memoria comunicativa ha come radice teorica le ricerche dell'antropologo Jan Vansina (1985) che analizza la concezione di storia nelle popolazioni africane notando come ci sia una scollatura fra il passato recente quello che circola quotidianamente nella comunicazione fra persone e quello remoto delle origini affidato ad una narrazione specializzata da parte di griot, bardi, contastorie che si occupa di preservarlo e di tramandarlo.

Mentre la memoria culturale ha parametri fissi, e la partecipazione è molto differenziata sia nelle dimensioni so- ciali semplici ed arcaiche, sia nelle dimensioni più avanzate e complesse. Si ottiene attraverso il contributo delle varie istituzioni culturali e il passato è rappresentato in simboli da miti orali o scritti. È composto e si articola in manifestazioni e strumenti culturali come feste, commemorazioni, libri, giornali, strade, teatri, film e monumenti, attraverso i quali riesce a trasferire e fissare il contenuto culturale che viene ricordato giunge al ricordo. Nella memoria culturale mito e storia si fondono in una cosa sola, ciò che è rilevante non è il passato di storici o archeologi, ma il passato come viene ricordato. La memoria riveste una funzione sociale e comunicativa. Il passato deve essere vicino in senso emotivo, deve essere il nostro passato, quindi strettamente legato al concetto di identità.

\section{MEDIARE, RI-MEDIARE L'IDENTITÀ E LA TRADUZIONE}

L'identità è un concetto di fondamentale rilevanza politica e culturale del nostro tempo, gli studi di traduzione non possono quindi prescindere dall'esaminare questo essenziale aspetto culturale.

La traduzione, si rivela uno strumento indispensabile, per cercare di comprendere accuratamente la natura identitaria di un gruppo, una comunità o del singolo, e della maniera in cui questi si interfacciano con la storia umana, fornisce una visione innovativa e positiva su come risolvere uno dei problemi più importanti in un mondo sempre più senza confini. La rilevanza della lingua e del linguaggio è chiara in tal senso, visto che il linguaggio ha il potere di unire e di dividere ed è ciò che interiormente ci differenzia come esseri umani che ci rende diversi gli uni dagli altri. Il traduttore, quindi, non può trascurare questo aspetto ed è colui che si deve fare carico di questa mediazione culturale. In tal senso Michael Cronin afferma:

The 'traces of difference' cannot be ignored, then, in a desire to float free of attachment or through some residual guilt about the pull of a culture or an identity (or a plurality of these) in a world where the fluid and the borderless and the emancipated are held up 


\section{LA MEMORIA “VIAGGIANTE” FRA IDENTITÀ E TRADUZIONE}

Entreculturas 11 (2021) pp. 53-68

as virtual synonyms. The difficulty, however, has been to make cosmopolitanism attentive to those differences, to the particular claims of singular locations, without which translation as a meaningful activity would cease to exist. If there are no singular locations, then there is nothing left to mediate and by extension nothing to translate (Cronin 2006: 12).

Pertanto, i luoghi e le storia della cultura di appartenenza influiscono, in misura più o meno ampia, nella costruzione mentale di una prospettiva di identità intesa in senso ampio, ovviamente, nella pratica traduttiva si segue l'intuizione che fu dell'umanesimo rinascimentale vale a dire che bisogna, secondo la necessità, sapersi svincolare dallo stato di cose che appartengono alle nostre origini. La forma mediante la quale i membri della società si rappresentano e rappresentano sé stessi agli altri, non è condizionata solo dalla propria storia, ma è anche legato al modo in cui nel mondo contemporaneo si è chiamati, animati o costretti esseri attori dell'economia e nella società (Cronin 2006: 2).

Cronin ci dice che con la crescita esponenziale del senso di incertezza o di percezione del rischio, in larga parte si alimenta la paura di una possibile minaccia, e cresce la tentazione di cercare una nozione di identità che sia inquadrata integralmente nel diritto economico e la allontani da qualsiasi idea di trasformazione collettiva e sociale che vada oltre le mere esigenze di una economia di mercato. In una società come quella in cui viviamo, in prevalenza composta da soggetti che consumano e/o considerati solo per tale caratteristica piuttosto che come soggetti attivi e partecipanti, che prendono parte alla vita sociale e politica, e non solo economica di quella che può essere una piccola o grande comunità urbana.

Il ruolo sociale, pertanto, viene definito più da ciò che si possiede in termini di ricchezza materiale e non da quello che realmente si è; tutto questo, in una società cosmopolita e globale può condurre al rischio di una reale regressione sociale in termini politici e di conseguenza a forme sempre più virulente di nazionalismo, nonostante l'apparente declino dello stato nazione. In uno sfondo del genere, l'identità perde il suo valore endemico di risorsa, tramu- tandosi in un elemento desolante e dai forti tratti solipsistici atti a conservare staticamente la propria condizione sociale, dimenandosi agonizzante fra un'economia globale e un materiale umano estremamente condizionabile.

In questo scenario la traduzione offre un apporto indispensabile nel descrivere la trasformazione, il condizionamento subordinato a determinate forme di concepire l'identità. Non meno rilevante è il percorso che la teoria e la pratica della traduzione possono indicare, un percorso costruttivo verso forme di mutuo scambio, coesistenza e abilitanti piuttosto che infestanti e distruttive:

The danger is that as a sense of uncertainty or risk becomes more and more prevalent, the temptation is to reach for a notion of identity which is wholly concerned with economic entitlement and detaches identity from any idea of collective, social transformation which goes beyond the needs of the market. Once we have individuals as consumers rather than as citizens, who are defined by what they have and will have rather than by what they are and, more importantly, might be, then we run the paradoxical risk of increasingly virulent forms of nationalism in a globalized world with its much vaunted decline of the nation-state. Identity in this scenario is the bleak, defensive interface between a global economy and infinitely malleable human material. It is in this context that the contribution of translation is paramount in describing both how certain forms of identity have come into being and how they are being shaped. Equally important is the manner in which translation theory and practice can point the way to forms of coexistence that are progressive and enabling rather than disabling and destructive. (Cronin 2006: 3)

Ricoeur riferendosi al concetto di identità, sostiene la necessità di comprendere l'esistenza di due modi di intenderla ovvero come medesimo, o come ipse da cui derivano il senso di "medesimezza" e di "ipseità". Secondo questa distinzione l'identità intesa come medesimo riguarda il carat- 


\section{S. Cristian Troisi}

tere di una persona, quell'aspetto immutabile e permanete nel tempo mentre il senso di ipseità è l'aspetto dato dalla narrazione di Sé, fenomeno che, sebbene mutevole, contiene anche esso delle costanti nel tempo. La prospettiva cosi come il legame temporale fra queste due modalità diverge: la medesimezza è ancorata al passato, mentre al contrario, l'ipseità tende al futuro. Il concetto viene così espresso dal filosofo francese:

[...] una distinzione, che non mi sembrava semplicemente di linguaggio ma di strutturazione profonda, fra due figure dell'identità: quella che chiamo la identità idem, la "medesimezza" (mêmeté) o sameness, e l'identità ipse, la "ipseità", selfhood. $\mathrm{Ne}$ fornisco immediatamente un esempio concreto: la medesimezza è la permanenza delle impronte digitali di un uomo, o della sua formula genetica; ciò che si manifesta al livello psicologico sotto forma del carattere: il termine "carattere" è d'altronde interessante, è quello che si utilizza nella stampa per designare una forma invariabile. Mentre il paradigma dell'identità ipse, per me, è la promessa. Manterrò, anche se sono cambiato; è un'identità voluta, mantenuta, che si prolunga ad onta del cambiamento.» (Ricoeur 1997: 133).

La nozione di memoria culturale in sé racchiude, nei sui aspetti essenziali, diverse affinità con alcuni basilari aspetti che caratterizzano la traduzione. Ad esempio, il passato può in qualche modo essere visto come il testo originale che è la fonte del successivo lavoro di traduzione in questo modo sia le ricerche di scienza de la traduzione che gli studi sulla memoria culturale sembrano coincidere nella possibilità di, ricostruire o usando termini husserliani "presentificare" ovvero rendere presente, cercando di ricrearla, una percezione assente che nel caso della traduzione viene rappresentato appunto dalla fonte (Agorni 2012: 28). Ne consegue, che:

Il passato è l'oggetto principale degli Studi sulla Memoria Culturale, che tuttavia non sembra caratterizzarsi tanto per un rigore di natura filologico nel riportare alla luce ciò che è lontano nel tempo, quanto in un desiderio di rappresentare un passato in movimento perché continuamente riadattato per rispondere alle conoscenze, necessità e interessi del presente. In modo molto simile, la traduzione ricostruisce il messaggio del testo fonte, adattandolo a esigenze e valori contingenti, cioè riferiti ad un preciso contesto storico e culturale che corrisponde al tempo della ricezione, necessariamente presente (Agorni 2012: 28).

Convenendo con Argoni (2012), nel caso della traduzione crediamo sia meglio sostituire il termine filosofico "presentificare" con mediare o ri-mediare di più recente concezione, più aderenti all'interpretazione dei fenomeni interculturali e transnazionali propri della traduzione e che sono la base degli studi sulla memoria culturale.

Mediazione, rappresenta la maniera in cui un messaggio si adatta nel suo passaggio da una realtà, un sistema, o un codice ad un altro.

Ri-mediare, è un concetto connesso allo studio dei new media e allo studio della memoria culturale che implica un processo di elaborazione e successiva rielaborazione delle fonti una "metamediazione" o ipermedialità, che attraversa diversi media:

It would seem, then, that all mediation is remediation. We are not claiming this as an a priori truth, but rather arguing that at this extended historical moment, all current media function as remediators and that remediation offers us a means of interpreting the work of earlier media as well. Our culture conceives of each medium or constellation of media as it responds to, redeploys, competes with, and reforms other media. In the first instance, we may think of something like a historical progression, of newer media remediating older ones and in particular of digital media remediating their predecessors. (Bolter e Grusin 1999: 55)

Sappiamo che la scelta delle strategie traduttive e gli sforzi del traduttore si canalizzano concretamente nel fa- 


\section{LA MEMORIA “VIAGGIANTE” FRA IDENTITÀ E TRADUZIONE}

Entreculturas 11 (2021) pp. 53-68

ticoso tentativo da parte di quest'ultimo di utilizzare le stesse scelte comunicative nella lingua meta di un madrelingua. Ovviamente, per raggiungere questo risultato e per la buona riuscita di un processo traduttivo, la figura del traduttore ha dovuto cambiare e trasformarsi.

Bisogna dire che nelle ultime tre decadi i Translation Studies (TS) si sono progressivamente andati affermando. In questo relativamente breve lasso di tempo si è assistito a un aumento vorticoso delle pubblicazioni aventi come tema centrale la traduzione nei suoi due aspetti descrittivi principali di prodotto e di processo. Tuttavia, sebbene la letteratura abbondi di tali pubblicazioni, i traduttori stessi, le persone atte a produrre i testi tradotti e coinvolte in prima persona nei processi di traduzione, hanno attirato stranamente poca attenzione finora (Dam e Zethsen 2009: 7). Ed ancora: "Under descriptive studies Holmes lists those oriented towards product, process or function. Since the products of translation are texts (including the oral variety), this branch on the map does not primarily relate to our new subfield." (Chesterman 2009: 15).

In questo panorama solo alcune pionieristiche ricerche come segnalano Dam e Zethsen (2009) hanno posto il traduttore come concetto centrale, diventando oggetto di studio privilegiato. Riconoscendogli, come già segnalava Simeoni (1998), una importanza rilevante come agente sociale ed artefice della traduzione:

Translating being an expertise whose enactment always occurs for particular reasons in a particular context, it is worth inquiring into the acquisition of a translator's style and skills in terms of their complex cognitive development. This raises of course the issue of the angle from which to study this cognitive emergence (Simeoni 1998: 2)

Chesterman (2009) nel suo articolo dal titolo esplicito ed evocativo «The Name and Nature of Translator Studies», che ricalca il noto articolo di Holmes (1988), a cui fa chiaro riferimento, e che costituisce la base del suo ragionamento teorico. In tale articolo Chesterman sostiene, appunto, che la figura del traduttore deve essere il punto di partenza imprescindibile della ricerca sulla traduzione, il focus esplicito, l'elemento primario; tutti gli sforzi di tale ricerca devono sicuramente muoversi verso l'artefice e non solo l'artefatto, implicare, in modo che siano effettivamente rivolti a ciò che c'è dietro le traduzioni e i testi, vale a dire, gli esseri umani, le persone, uomini e donne, quel groviglio di vissuti, emozioni inestricabili, culture, costumi, quotidianità ecc. che si celano dietro a una "semplice" traduzione:

\begin{abstract}
As a simple preliminary definition, let us say Translator Studies is the study of translators (and of course interpreters). Of course, all research on (human) translations must surely at least imply that there are indeed translators behind the translations, people behind the texts. But not all translation research takes these people as the primary and explicit focus, the starting point, the central concept of the research question (Chesterman 2009: 13-14)
\end{abstract}

Di conseguenza, ciò che propone Chesterman nei sui Studi sul traduttore, è di relegare il testo a un ruolo secondario dando maggiore importanza al traduttore. Questa nuova priorità implica questioni di ricerca differenti, non escludendo, naturalmente, che anche le ricerche orientate al prodotto possano rivelare informazioni interessanti sulle persone dietro $i$ testi.

Alla luce della recente "svolta sociologica" negli Studi di Traduzione profetizzata da Holmes nella sua proposta di una "sociologia della traduzione" come futuro settore di ricerca, Chesterman (2006) suggerisce 3 filoni dei quali è interessante porre in evidenza quello in cui il traduttore riveste il ruolo centrale per comprenderne l'essenza del ragionamento:

The sociology of translators covers such issues as the status of (different kinds of) translators in different cultures, rates of pay, working conditions, role models and the translator's habitus, professional organizations, accreditation systems, translators' networks, copyright, and soon. Questions of a different kind under this heading are those relating to gender 


\section{S. Cristian Troisi}

Entreculturas 11 (2021) pp. 53-68

and sexual orientation, and to power relations, and how these factors affect a translator's work and attitudes. The sociology of translators also covers the public discourse of translation, i.e. evidence of the public image of the translator's profession, as seen e.g. in the press, or in literary works in which one of the central characters is a translator or interpreter (Chesterman 2009: 16)

Concetto che viene ribadito da Tyulenev, dove il traduttore è osservato come un individuo, immerso nel tessuto sociale e culturale della propria citta, regione o nazione di origine e per questo, l'aspetto sociale del suo comportamento è solo una parte di un insieme più complesso, nel quale entrano in gioco inevitabilmente: i suoi sentimenti personali, le emozioni, i tratti del carattere, la volontà, l'abilità e anche lo stato fisico dell'organismo che può senza dubbio influenzare le prestazioni professionali del traduttore. Pertanto, non è solo la società a influenzare gli individui ma anche quest'ultimi influenzano inevitabilmente la società in una relazione di influenza reciproca:

If the translator is inevitably an individual, although a socialised one (that is, one who has internalised the culture of the society into which s/he was born), then obviously the social aspect of his/her behaviour is only a part of a more complex whole. There still are his/her personal feelings, moods, character traits, will, abilities and even physical states of the organism, which can affect the translator's professional performance. The individual inescapably influences the social. You may be a very good professional interpreter but this morning you may have a headache; this may make your performance in the business conference in which you are interpreting somewhat below your usual standard; you may have to concentrate harder and still make a few slips here and there with phrases that otherwise would be plain sailing for you. Or you may dislike a particular topic, but being an in-house translator you will be asked to translate texts on that particular topic and feel that your translations come out not as inspired as your versions of texts on other subjects. Over years, as you gain experience, you will be able to control your performance more and more efficiently, although your individuality will never disappear. In reality, the individual and the social are two extremes of one continuum. Every translational decision is an interface between the translator's own individuality and the society of which s/ he is a part. (Tyulenev 2014:11)

A questo gruppo possiamo ascrivere anche Pym (2009), anch'egli sottolinea, infatti, la carenza di considerazione nei TS nei confronti degli agenti sociali che sono coinvolti nel processo produttivo. Evidenziando l'importanza del traduttore in quanto mediatore fra culture. Nella sua proposta di "umanizzare" gli studi traduttologici suggerisce come elemento propedeutico, ancor prima del testo, per la buona comprensione di una traduzione, lo studio del traduttore.

Dicevamo che negli ultimi anni, è stata superata l'obsoleta logica mimetica che vedeva la traduzione semplicemente come il meccanico raggiungimento di una equivalenza linguistica ma che non comprendeva tutte quelle dinamiche di mediazione e di ri-mediazione insite nel processo traduttivo. Si è iniziato a pensare alla traduzione più come a un processo dinamico che prendeva in considerazione le diverse reti semantiche caratterizzanti le varie culture, mettendo in risalto i tratti di mediazione transculturale insiti nella scienza della traduzione. Ciò ha comportato un cambio, una evoluzione trasversale delle competenze traduttive che si sono allargate, diversificandosi e specializzandosi, a cui necessariamente si sono aggiunte competenze di natura extralinguistica, storico-antropologica, socioculturale, etnologica, professionale e tecnica oltre alle già necessarie competenze linguistiche specialistico-settoriali di vario genere. A questo proposito Pym:

As an interpersonal activity working on texts (of whatever length or fragmentary status), the training of translators involves the creation of the following two-fold functional competence (cf. Pym 1991):

- The ability to generate a series of more than one viable target text (TTI, TT2 ... TTn) for a pertinent source text (ST); 


\section{LA MEMORIA “VIAGGIANTE” FRA IDENTITÀ E TRADUZIONE}

Entreculturas 11 (2021) pp. 53-68

- The ability to select only one viable TT from this series, quickly and with justified confidence.

We propose that, together, these two skills form a specifically translational competence; their union concerns translation and nothing but translation. There can be no doubt that translators need to know a fair amount of grammar, rhetoric, terminology, computer skills, Internet savvy, world knowledge, teamwork cooperation, strategies for getting paid correctly, and the rest, but the specifically translational part of their practice is strictly neither linguistic nor solely commercial. It is a process of generation and selection, a problem-solving process that often occurs with apparent automatism. (Pym 2003: 489)

Di fatto la traduzione di frequente si può trasformare in una pratica estremamente articolata, un atto le cui capacità traduttive, e non solo, dipendono dall'interazione tra noi e il mondo circostante, essendo la conoscenza distribuita nel mondo in cui viviamo, dimora nel nostro cervello poiché parte da dentro e diventa compiuta nei vincoli operativi che il mondo ci impone:

\begin{abstract}
Le informazioni sono nel mondo. Molta dell'informazione che ci serve per eseguire un compito può risiedere nel mondo esterno. Il comportamento si determina combinando l'informazione in memoria (nella nostra testa) con quella presente nel mondo. [...]. Sono presenti vincoli culturali. Oltre ai limiti fisici, naturali, la società ha sviluppato numerose convenzioni culturali che devono essere apprese, ma una volta apprese si applicano a un ampio ventaglio di circostanze (Norman 1997: 66-67).
\end{abstract}

Quindi, d'importanza fondamentale è il rapporto fra le memorie e la mente e la sua interazione con il mondo esterno, che si costituisce di supporti e strumenti di vario genere.

Pertanto, possiamo affermate che: «Il tradurre, in quanto processo cognitivo ampiamente basato sulla conoscenza di due sistemi linguistici nelle loro varie componenti semantico-strutturali, si regge per larga parte su un continuo lavoro di memorizzazione e di richiamo alla memoria di dati linguistici e di associazioni tra elementi in lingua straniera ed elementi nella propria lingua madre» (Peverati 2014: 42)

Di conseguenza, la capacità di recuperare nuove informazioni linguistiche ed extralinguistiche e di determinarne la qualità attraverso una vasta serie di strumenti come i dizionari, enciclopedie, motori di ricerca, i quali si aggiungono ad un vasto archivio di informazioni plurilingue già incontrate come glossari, banche dati terminologiche e memorie di traduzione, realizzate grazie ad appositi software a partire da lavori di traduzione precedentemente e che formano parte di una "memoria" che sarà funzionale a un futuro utilizzo.

Peverati citando Christensen (2011) dice che, in un certo senso, questi artefatti forniscono alla figura del traduttore una "supplementary long-term memory from which past information can be retrieved in the future" e quindi possono essere di fatto definiti come strumenti del "fare memoria" nel caso particolare della traduzione. (Peverati 2014: 42)

Concetto che in altri termini viene ribadito in questi termini da Pym:

[...] what happens in the actual process of translating, to the cognitive movements between languages and between texts, what extension of our perception is most radically affected? The answer, I suggest, must be memory. What has most been extended, and keeps being extended, is the capacity to store and retrieve knowledge, and to do so externally to the mind. Memory is the process dimension most affected by technology, and never more so than in an age of electronic communication (Pym 2011: 1).

L'incremento dell'uso di mezzi offerti dall'avanzare delle nuove tecnologie, offre sicuramente un ausilio importante alla professione del traduttore. La maggior parte degli strumenti elettronici, asserisce Pym, sono semplicemente tecniche che accelerano e ampliano la produzione di testi tradotti rendendo così disponibili, diversi testi alternativi, questo può designare la maniera di utilizzare il web da parte dei traduttori; altri apprezzabili strumenti sono 


\section{S. Cristian Troisi}

le estensioni, come: memorie di traduzione e glossari che consentono di filtrare e scartare di forma autorevole le alternative che si presentano.

I traduttori producono e selezionano tra le varie alternative, dunque, le molteplici nuove tecnologie non alterano questi compiti, ma semplicemente li rendono più "wider-ranging”, precisamente, prendendo in esame più cose pertinenti al mondo che ci circonda in meno tempo. In tal senso, una visione minimalista della competenza dovrebbe aiutarci a tenerci consapevoli dei fini dei propri compiti, senza perderci nei mezzi (Pym 2003: 493).

Di sicuro l'uso della memoria di traduzione TM che è alla base dei CAT tools che operano proponendo segmenti di traduzione ma che non sempre si rileva un mezzo idoneo per eseguire delle traduzioni di qualità. A volte i segmenti usati si rilevano poco precisi compromettendo così la qualità del prodotto finale. Questa situazione è dovuta al fatto che i compensi sono ridotti, di conseguenza il traduttore valuta in maniera superficiale segmenti proposti dalla memoria e li accetta, nonostante questo contenga delle lievi inesattezze.

The possibility of re-using previous translations means that clients ask translators to work with TM systems and then reduce the translator's fees. The more exact and fuzzy matches (equal and similar segments already translated and included in the database), the less they pay. This encourages translators to work fast and uncritically with the previously translated segments, with a corresponding decline in quality. When higher quality work is required, special emphasis must be put on revising the outputs of translation-memory tools. (Biau Gil e Pym 2006: 10)

Ribas López (2007) evidenzia come accettando questi segmenti imprecisi non si faccia altro che reiterare l'imprecisione dato che inseriti in memoria continueranno a generare una futura catena di imprecisioni.

Bowker (2002) nel suo Computer-Aided Translation Technology: A Practical Introduction parlando dell'uso di queste tecnologie a supporto della traduzione ne eviden- zia i limiti sottolineando che il contenuto delle memorie con il passare del tempo si rivela obsoleto soprattutto sotto l'aspetto contenutistico e terminologico.

Dietro al termine memoria come abbiamo osservato si celano significati ed interpretazioni e articolazioni caleidoscopiche. A sua volta, osserviamo come essa sia strettamente correlata alla scienza della traduzione e alla traduzione.

Lasciamo da parte il significato dell'uso della memoria nel campo della tecnologia della traduzione per esaminare più da vicino la memoria, la memoria culturale, l'identità e la traduzione.

Lo studio della memoria culturale è di natura diacronica e considera l'evoluzione delle storie "reali", che spesso vengono selezionate e comunicate a quei campi "normativi" che forniscono supporto alle generazioni future (Rigney 2005: 16).

La componente base della memoria è la trasmissione, che ne costituisce la logica di base, la cui matrice ed esistenza si esprime attraverso un'incessante mobilità spaziale e temporale, e che si sviluppa grazie allo scambio incessante di informazioni tra individui, gruppi e culture, oltre che tra i diversi social media.

Movimento che fornisce l'amnios metaforico di cui il testo si nutre per venire alla luce. E, riferendoci alla memoria, va menzionato inoltre il ruolo della traduzione che è quello di fare da ponte temporale creando altresì, la possibilità stessa che tale testo possa essere tramandato, diventando memoria. Tale concetto viene espresso da Bollettieri Bosinelli e Torresi:

Il primo elemento di tale metafora genitoriale è che è solitamente grazie alla traduzione se un testo può entrare in un nuovo mondo, o come direbbe EvenZohar (1990), un nuovo polisistema letterario. In questo polisistema di arrivo lo stesso testo, se non fosse tradotto, sarebbe del tutto assente o avrebbe una rilevanza solo marginale, perché sarebbe conosciuto solo da persone che conoscono la lingua in cui è scritto e che possono quindi entrarvi in contatto senza la mediazione di agenti istituzionali. Poi, una volta che il testo tradotto inizia a condurre 


\section{LA MEMORIA “VIAGGIANTE” FRA IDENTITÀ E TRADUZIONE}

Entreculturas 11 (2021) pp. 53-68

un'esistenza separata in ciascuno dei rispettivi polisistemi di arrivo, può accadere che una o più versioni tradotte si guadagnino un posto più centrale, nel proprio polisistema di riferimento rispetto a quello occupato dall'originale nel polisistema di partenza. In questi casi, la traduzione può assicurare la sopravvivenza del testo anche quando il polisistema di partenza è un ambiente ostile all'opera, come accadde per esempio all'Ulisse di James Joyce (1922), le cui prime traduzioni tedesca e francese (rispettivamente Joyce 1927, tradotto da Goyert, e 1929 tradotto da Morel et al.) incontrarono un enorme successo, e furono usate. Seguendo ancora la terminologia di Even-Zohar (1990), diventa un repertorio attivo nel polisistema di arrivo, generando nuove interconnessioni che non sono disponibili per il testo originale, ma diventano possibili solo dopo la traduzione (Bollettieri Bosinelli e Torresi, 2012: 18).

Si può dire che la traduzione assicurando la presenza di un testo in diversi polisistemi getta le basi per la sua conservazione e che di esso si tenga memoria in polisistemi letterari e culturali corrispondenti a tutte le aree linguistiche in cui è o è stato in circolazione. In questa prospettiva, la distinzione tra l'"originale" e le sue "traduzioni" percepite come derivate perde la sua rilevanza perché tutte le versioni del testo, compreso l'originale rivitalizzato sotto il proprio polisistema di riferimento, sono figli dello stesso processo traduttivo da cui traggono vita e vitalità. In questa prospettiva l'originale, o meglio il testo scritto nella lingua d'origine, pur essendo innegabilmente il punto di partenza del processo di traduzione, non occupa un posto centrale o gerarchicamente dominante. (Bollettieri Bosinelli e Torresi 2012: 20)

Ora, in questa "traduzione viaggiante" polisistemica, dobbiamo tener conto dell'intraducibilità, in particolare di come si possa tradurre la memoria culturale e l'identità culturale.

Comunemente quando parliamo d'intraducibilità, spesso ci si limita a considerare oggetto della questione l'aspetto letterario ed in senso stretto quello linguistico. È opinione diffusa che esistano generi letterari più o meno difficili da tradurre e che la produzione lirica, per l'uso di figure retoriche, i continui rimandi metaforici e non, alla cultura di appartenenza, figuri come oggetto di più difficile traduzione rispetto ad altri anche se in molti casi la poesia rappresenta un ipertesto transculturale visto che sovente vi sono rimandi ad altre culture anche se filtrate da quello che è il punto di vista dominante che è costantemente quello della cultura di partenza. Se solo considerassimo la lingua standard come lingua di partenza ci troveremmo già difronte ad innumerevoli difficoltà di traduzione che vedono il suo apice nei giochi di parole, i calembour, proverbi e realia una vera e propria sfida per i traduttori. Non vi è ombra di dubbio che il problema non sia solo linguistico ma più vasto e complesso, tutti i tipi di riferimenti alle peculiarità della cultura di origine a cui appartiene il testo originale causeranno seri problemi di traduzione, e se non possiamo arrivare a una totale intraducibilità dell'opera, si determinerà la perdita di molti dei suoi riferimenti culturali o la loro seria compromissione.

L'intraducibilità spesso si tramuta in perdita dell'informazione culturale e conseguentemente del contenuto identitario della cultura del testo originario. Semplicemente considerando un livello linguistico molto elementare, chi si occupa di traduzione è cosciente della mancanza di equivalenza tra le lingue già a livello lessicale. Prendendo in esame il livello denotativo vale a dire quello primario, letterale ed oggettivo e quello connotativo, allusivo e soggettivo delle singole parole si scopre subito la divergenza linguistica fra due lingue. Basti pensare alla parola guardia civil in spagnolo che a livello denotativo si potrebbe tradurre in poliziotto o tuttalpiù in alcuni casi in finanziere ma che non avrebbe lo stesso livello connotativo che possiede in spagnolo o sempre la parola riferita alle forze dell'ordine, recentemente alla ribalta mozos de escuadra, in catalano mossos d'esquadra che tradurrebbe anch'essa poliziotto ma di diversa connotazione sia culturale che politica. La parola littorina che indica una automotrice a trazione termica connota sia geograficamente (visto che in alcune regioni del sud Italia è ancora in uso) che storicamente il lemma, da cui deriva il diminutivo littorine- 


\section{S. Cristian Troisi}

$\mathrm{lla}^{1}$ (termine probabilmente ancora in uso in Eritrea) con il quale venivano soprannominate le piccole automotrici FIAT a due assi, costruite nel 1935 e impiegate ad Asmara e che comprensibilmente una traduzione con il semplice termine automotrice non renderebbe a pieno. Ovviamente ogni lingua possiede dei riferimenti fortemente storico-culturali, una serie di parole e frasi legate indissolubilmente al territorio da cui ha avuto inizio la propria genesi.

Infine, c'è il significato che ci viene da informazioni aggiuntive che non sono obbligatoriamente connesse in forma esclusiva e trasparente all'oggetto del discorso. Come abbiamo già avuto modo di notare, si tratta della memoria nelle sue declinazioni collettive, comunicative, culturali, sociali, linguistiche, geografiche, e storiche che in maniera spesso inconscia e codificata è trasmessa dall'emittente nella propria lingua d'origine. Vi sono poi concetti e espressioni gergali, realia, modismi o proverbi che sono fortemente vincolati alla cultura emittente e che tradotti diventano avulsi alla cultura ricevente.

Questo avviene con «espressioni come parlare ostrogoto; fare alla romana; piove, governo ladro; fare i portoghesi; mangiare a ufo, espressioni indissolubilmente legate ad un passato storico altresì mitico di un popolo che riverberano nella propria lingua che sono di semplice traduzione a livello denotativo e connotativo, si potrebbe, appunto, rendere maciste con uomo molto forte o invece fare i portoghesi con entrare senza pagare, con la evidente conseguenza di escluderne ogni riferimento culturale» (Wozniak 2009: 172).

La cosa si complica ancor di più quando il lessico o la fraseologia in questione fanno parte del corpus letterario di una nazione e percepite come parte integrante dell'identità nazionale, come il giardino di Armida; il paese dei Balocchi; un girone infernale; essere un carneade; un azzeccagarbugli; la Fata Turchina; fare il grillo parlante; fare il Gradasso che fanno riferimento a dei classici canonici della cultura della lingua di partenza (nello specifico italiana) e nella fattispecie la Divina Commedia, Orlando Furioso, I promessi sposi e Pinocchio (Wozniak:2009:172). Nel caso citato:

1 Cfr. https://www.laputa.it/lexicon/littorina/
[...] il livello del significato evocato non si limita in questo caso ad aggiungere un'informazione in più, ma influenza anche il livello del significato denotativo e connotativo. Infatti, per capire tutte le implicazioni del termine azzeccagarbugli non basta sapere che esso significa più o meno leguleio da strapazzo, ma bisogna tener presente il personaggio descritto vivacemente da Manzoni nei Promessi sposi. [...] Allo stesso modo il concetto di Paese dei Balocchi si tinge di una sfumatura diversa, se uno si rende conto in che modo era finita l'avventura di Pinocchio in quel posto. Ci sono poi delle parole e delle espressioni radicate così profondamente nella mentalità della CP che al di fuori di essa sembrano di perdere ogni ragion di esistere. Citiamo la parola burla, burlarsi che rimanda direttamente alla tradizione teatrale della commedia d'arte, oppure un'espressione come in zona Cesarini che combina il ricordo di un calciatore degli anni Trenta del secolo scorso, con l'indicazione della smisurata passione degli italiani per il calcio. A quali soluzioni può ricorrere in tali casi il traduttore? Realisticamente parlando, le possibilità di manovra sono piuttosto limitate. Per quanto riguarda le espressioni di provenienza letteraria, "trapiantare" il loro bagaglio culturale nella LA risulta pressoché impossibile, anche nei casi in cui esse alludono a un'opera precedentemente tradotta in LA. È poco probabile, infatti, che il testo in questione abbia nella LA lo stesso status di cui gode nella LP. (Wožniak 2009: 173)

Il compito si fa più gravoso nel momento in cui si deve affrontare la traduzione di: dialetti, regionalismi e culturemi che sono parte integrante della cultura di un popolo. Basti pensare a quell'impasto fra italiano e dialetti, il plurilinguismo che troviamo nei romanzi di Andrea Camilleri, Carlo Emilio Gadda, Vincenzo Consolo, Dario Fo, ecc.

Mair (1992) asserisce che il dialetto ha un potere ed un valore caratterizzante, definendo quelle che sono le peculiarità di un personaggio o le caratteristiche dell'autore di un testo letterario. Mair classifica le funzioni del dialetto nella 


\section{LA MEMORIA “VIAGGIANTE” FRA IDENTITÀ E TRADUZIONE}

Entreculturas 11 (2021) pp. 53-68

letteratura in mimetiche che sono quelle che definiscono il modo di esprimersi, e simboliche, ossia il modo di sentire e di percepire le cose, la parte intima che inequivocabilmente cerca di stabilire una consonanza affettiva con lettore.

In relazione ai dialetti, Muñoz (1995) si focalizza sui dialetti sociali e geografici distinguendone l'intenzionalità e la non intenzionalità da parte dell'emissore nell'uso, e asserendo che rivestano una funzione concreta nel testo e rispecchiando lo stile degli stessi emissori nel caso in cui sia utilizzato con volontarietà.

Il difficile compito del traduttore e quello di restituire quella dimensione sociale, culturale e geografica tipiche della comunità linguistica d'origine. Quella visione del mondo, che è altra e come afferma Tyulenev, è forse la sfera più completa in cui il sociale e l'individuo si intrecciano:

\begin{abstract}
Worldview or, to use the original German term Weltanschauung, is yet another and perhaps the most comprehensive sphere in which the social and the individual are intertwined. Worldview is a rather amorphous notion embracing religious beliefs, scientific knowledge and moral and aesthetic values. It encompasses what may be generally termed as a conception of the world or a philosophy of life. Each individual has a worldview, which ultimately can be traced to the society or societies in which their worldview was formed and developed. This comprehensive domain is ultimately responsible for making us representatives of particular cultures - bearers of at least some of our home-cultural traits, for example, body language, food preferences, views about family and kinship unity, etc. (Tyulenev 2014: 11)
\end{abstract}

Il nucleo problematico è rappresentato dal raggiungimento di quel complicato equilibrio fra il testo di partenza ed il testo meta, e della mediazione interculturale considerando: «che siamo costretti a confrontarci con criteri delicati come ritmo, musicalità e stile, ossia tutti quegli elementi imponderabili grazie ai quali la sfida della traduzione letteraria è in grado di appassionare, avvincere e trasportare il traduttore ma anche lo stesso lettore a tal punto da farlo addentrare nel testo e nella cultura da cui ha preso origine» (Troisi 2020: 67)

Non andremo ad indagare sulle tecniche traduttive che si possono applicare o gli espedienti linguistici che è possibile porre in atto, quello che a questo punto ci preme sottolineare è la necessità da parte del traduttore nel suo lavoro di mediazione e ri-mediazione di tenere conto del concetto di ipse, mutuato da Recoeur per definire una delle caratteristiche dell'identità ed applicato alle scienze della traduzione come: la capacità di riconoscersi al di là delle sue trasformazioni nel tempo ed alla quale aggiungiamo a questo concetto la dimensione spaziale che è propria del trasferimento dei culturemi che è insito nell'atto traduttivo. Quindi, citando nuovamente le parole di Ciaramelli, ciò implica che «La dialettica ipseità/alterità, costitutiva della trama stessa della soggettività, è una dialettica dell'implicazione, e non dell'esclusione o dell'integrazione» dunque implicazione, vista come sviluppo, conseguenza logica e necessaria per la crescita personale ed umana.

Poiché, è 1'“altro" e l'alterità intesa come diversità di memorie, difformi dalla propria cultura o da quella dominante o autoctona che mette in atto una sorta di narrazione con la sua vivace esternalità, che si fa ricordo aderendo alla dimensione sociale del mondo, e lo affranca dalle ottenebrate illusioni solipsistiche.

Ciò che costitutivamente entra in connessione in ciascun essere vivente è rappresentato da ciò che è altro, che fa di ogni soggettività e della memoria ad essa ineluttabilmente connessa un punto di vista che compone la memoria culturale, una implicazione comune, una costruzione, uno sguardo esterno e oggettivo della realtà più intima.

Ancora Cronin, fa notare quello che lui definisce "entropic paradox", presente in un certo numero di presentazioni cioè il modo «in which presenters repeatedly drew attention to the importance of translation in culture, language and society and then systematically proceeded, using a variety of tools, to show how existing translations were failing to be adequate or accurate or competent» (Cronin 2006: 128)

Prosegue affermando che queste analisi affascinanti hanno mostrato come ci siano gravi lacune nella compren- 


\section{S. Cristian Troisi}

sione e nell'espressione, indipendentemente dal fatto che taluni fallimenti fossero motivati da pregiudizi politici, incompetenza linguistica, pregiudizi di genere o limitazioni materiali delle tecnologie esistenti. In altre parole, le presentazioni al pari degli innumerevoli articoli presentati alle conferenze mondiali sulla traduzione hanno continuamente provato che la traduzione come trasformazione implica perdita, falsificazione, pregiudizio e distorsione. Mentre le presentazioni erano chiaramente nel contesto della ricerca traslazionale descrittiva, le descrizioni erano così ritualmente focalizzate su assenze e approssimazioni che le conclusioni entropiche erano inevitabili (Cronin 2006: 128). Conclude con una proposta che condividiamo: «What we would like to propose is precisely a way of thinking about translation and identity which is grounded in cultural negentropy. This negentropic translational perspective is primarily concerned with the 'emergence of new' cultural forms through translation practice and the way in which translation contributes to and fosters the persistence and development of diversity» (Cronin 2006: 129).

\section{CONCLUSIONI}

In ultima analisi si è visto come memoria, identità e traduzione siano intimamente legate da qualcosa di indissolubile che è compreso nell'essenza umana. Il quadro che si è delineato ha mostrato come gli studi di memoria culturale e la scienza della traduzione generalmente, sia pur differenziandosi, condividano o debbano condividere l'impianto metodologico ed il piano strategico, considerando che tutte hanno in comune il movimento, i simboli, la migrazione ed il viaggio attraverso lo spazio ed il tempo.

Vi è la necessità di pensare o ripensare alla traduzione come promozione del nuovo, inteso come locale e marginale. Attraverso la pratica della traduzione si contribuisce e si favorisce la persistenza e lo sviluppo della diversità. La traduzione dell'alterità culturale implica l'uso delle facoltà cognitive e fisiologiche, in quest'ottica si ha l'impressione che il legame tra memoria e traduzione prenda ancor di più corpo e consistenza.

\section{BIBLIOGRAFIA}

Agorni, M. (2014): «La mediazione della memoria negli studi sulla traduzione», in Agorni, M. (ed.), Memoria, Lingua, Traduzione, Milano, Franco Angeli, pp. 27-40.

Betancourt Echeverry, Dario (2004): «Memoria individual, memoria colectiva y memoria histórica: lo secreto y lo escondido en la narración y el recuerdo» in La práctica investigativa en ciencias sociales, Bogotá, UPN, pp.123-134

Biau, G., José, R., \& Pym, Anthony (2006): «Technology and (a pedagogical overview)», in Pym, Perekrestenko, Starink (Eds.), Translation Technology and its Teaching. Tarragona: Intercultural Studies Group, Tarragona, Universitat Rovira i Virgili, pp.5-21.

Bollettieri Bosinelli, Rosa Maria e Torresi, Ira (2012): «Messaggi in bottiglia: tradurre memoria, memorie della traduzione», in Arigoni, Mirella (Ed.) Memoria lingua traduzione, Milano, FrancoAngeli, pp. 17-27.

Bolter, J. David, e Grusin, Richard (1999): Remediation. Understanding New Media, Cambridge Massachusetts, MIT Press.

Bowker, Lynne (2002): Computer-aided Translation Technology: A Practical Introduc- tion, Ottawa, University of Ottawa Press.

Callmann-Lévy, Paris, trad. it. Iannotta D. (1997): La critica e la convinzione, Jaca Book, Milano.

Chesterman, Andrew (2006): «Questions in the sociology of translation. » in Ferreira Duarte, João/Assis Rosa, Alexandra/Seruya, Teresa (eds.), Translation Studies at the Interface of Disciplines. Amsterdam: Benjamins, pp. 9-27.

Chesterman, Andrew (2009): «The Name and Nature of Translator Studies». Hermes: Journal of Language and Communication Studies, 42, 13-22.

Christensen, Tina Paulsen (2011): Studies on the mental processes in translation me- mory-assisted translation. The state of the art". trans-kom. Zeitschrift für Transla- tionswissenschaft und Fachkommunikation 4 (2): 137-16

Ciaramelli Fabio (1991): Ipseità, alterità e pluralità. Nota sull'ultimo Ricoeur, in «Aut Aut», 212, pp. 91-103.

Committee on Culture, Youth, Education, Media and Sport (2003): Report on Cultural Industries, Strasbourg: European Parliament, 14 July. 


\section{LA MEMORIA “VIAGGIANTE” FRA IDENTITÀ E TRADUZIONE}

Entreculturas 11 (2021) pp. 53-68

Cronin, Michael (2006): Translation and identity. Routledge. London

Dam, Helle, Karen Korning Zethsen (eds). (2009): «Translation Studies: Focus on the Translator», Hermes: Journal of Language and Communication Studies, 42, pp. 7-12.

Erll, Astrid (2011): Travelling memory. Parallax, 17(4), 4-18.

Halbwachs, Maurice (2001): La memoria collettiva, tr. di P. Jedlowski e T. Grande, Milano Unicopli.

Holmes, James S. (1988): «The Name and Nature of Translation Studies», in Holmes, J.S., Translated! Papers on Literary Translation and Translation Studies. Amsterdam: Rodopi, 67-80. Reprinted e.g. in Venuti, L. (ed.) 2000, The Translation Studies Reader. London: Routledge, pp. 172185.

Mair, Christian (1992): «A methological framework for research on the use of nonstandard language in fiction». AAA: Arbeiten Aus Anglistik Und Amerikanistik, vol. 17, no. 1, pp.103-123.

Molano, Olga Lucía (2007): «Identidad cultural un concepto que evoluciona.» Revista opera, 7, pp. 69-84.

Muñoz Martín, Ricardo (1995): Lingüística para traducir, Barcelona, Teide, pp. 5-42.

Norman, Donald Arthur (1997): La caffettiera del masochista. Psicopatologia degli oggetti quotidiani, Firenze, Giunti (ed. orig.1988).

Peverati, Costanza (2014): «Le memorie come supporto alla traduzione. Aspetti socio-professionali e didattici», in Agorni, Mirella (ed.), Memoria, Lingua e Traduzione, Milano, Franco Angeli, pp. 41-72.

Pym, Anthony (2003): Redefining translation competence in an electronic age. In defence of a minimalist approach. Meta: journal des traducteurs/Meta: Translators' Journal, 48(4), 481-497.

Pym, Antony (2009): «Humanizing Translation History», in Hermes: Journal of Language and Communication Studies, 42, pp. 23-49.

Ribas López, Carlota (2007): Translation Memories as Vehicles for Error Propagation. A Pilot Study. Minor Dissertation. Tarragona: Universitat Rovira i Virgili.

Rigney, Ann (2005): «Plenitude, scarcity and the circulation of cultural memory», Journal of European Studies 35 (1), pp.11-28.
Simeoni, Daniel (1998). «The pivotal status of the translator's habitus», in Target. International Journal of Translation Studies, 10(1), York, University of Toronto, pp. 1-39.

Troisi, S. Cristian (2020): «Le mille notti di Hotensia Romero», in Estudios interdisciplinares en traducción literaria y literatura comparada, Granada, Comares.

Tyulenev, Sergey (2014): Translation and Society. Londres: Routledge.

Vallespir Soler, Jordi (1999) «Interculturalismo e identidad cultural.», in Revista Interuniversitaria de formación del profesorado, 36, Universidad de Murcia, pp. 45-56.

Vansina, Jan (1985): Oral Tradition as History. Madison, U of Wisconsin P.

Wožniak, Monica (2009): «Tradurre la memoria culturale codificata nel lessico:(molte) domande e (poche) risposte», in Tempo e memoria nella lingua e nella letteratura italiana, Atti del XVII Congresso A.I.P.I, Bruxelles. 